\title{
Willingness to Pay for Managerial Training: A Case from the Knitwear Industry in Northern Vietnam
}

\author{
Aya Suzuki \\ University of Tokyo \\ Vu Huang Nam \\ Foreign University, Vietnam \\ Tetsushi Sonobe \\ National Graduate Institute for Policy Studies
}

May 2013

\begin{abstract}
Managerial capital has received attention in recent years as one of the major determinants for enterprise productivity, growth, and longevity. While recent empirical studies make it clear that training intervention can improve the management level, it remains unclear why the managers had not made efforts to obtain these basic knowledge. To test the hypothesis that the reason lies in low valuation for obtaining knowledge, we conduct experimental training programs for the managers of SMEs in a knitwear cluster in rural town in Vietnam. We find that the demand for these trainings was indeed low prior to trainings, but increased greatly with own learning experience, and that those with a higher prior demand tended to benefit more from the training. We also examine the spill-over effects from their peers and find their heterogeneous impacts across the types of trainings conducted.
\end{abstract}




\section{Willingness to Pay for Managerial Training: A Case from the Knitwear Industry in Northern Vietnam}

\section{Introduction}

Managerial capital, or the ability to manage a business, has received attention in recent years as one of the major determinants of enterprise productivity, growth, and longevity (Bruhn et al., 2010; McKenzie and Woodruff, 2012). Several studies have assessed the impacts of managerial training intervention on business performance, finding positive results (e.g., Bloom et al., 2011; Karlan and Valvida, 2011; Mano et al., 2012). These studies make it clear that many enterprises in developing countries are indeed poorly managed. Moreover, the empirical results of these studies indicate that even short-term basic business training can improve their management practices.

It remains unclear why this has been the case, however. These experimental training programs teach only very standard or basic business practices (such as the importance of keeping business records, advertising, and saving costs), which managers could easily learn from sources other than these programs if they wish to. Although most of these training programs studied are offered for free, the average take-up rate for the offer of training programs surveyed was only about 65 percent (McKenzie and Woodruff, 2012). The following have been identified as potential constraints, (a) they may simply be unaware of the value of training (information failure), (b) they may face credit constraints, (c) there may be supply-side constraints, and/or (d) they may have little incentive to invest in training in light of positive externalities to non-investors (McKenzie and Woodruff, 2012).

One of the purposes of this paper is to examine the extent to which the value of 
learning about management practices is unknown to business people in developing countries. We collected data from the managers of small and medium enterprises producing knitwear in a suburb of Hanoi, the capital of Vietnam, before and after basic business training was provided for more than 100 managers in our sample. This was a research project funded by the World Bank. We designed the training programs together with local and international business consultants, who also served as instructors, and conducted the baseline and follow-up surveys. The project had two training programs of different modes: a classroom training program in which trainees study in a classroom and an on-site training program in which instructors visit trainees' workshops.

The second purpose of our study is to examine which type of training is more effective. While the results of several business training experiments have been reported in the recent literature, most of them assess the impacts of only one type of training (McKenzie and Woodruff, 2012). However, in the world of development assistance practice, various types of training are also commonly conducted, such as hands-on consultation, peer-group discussion, and plant visits. Moreover, there can be a variety of ways in which the same subject is taught and a variety of combinations of different subjects in a training program. The preceding studies have paid little attention to the issues of what should be taught and how, with a major exception of Drexler et al. (2010). The current paper is a small step in this direction of research on the role that management training can play in industrial development assistance.

Our study site is a cluster of small and medium-sized knitwear enterprises previously studied by $\mathrm{Vu}$ et al. (2010). Most studies of management training look at the impacts of a training program on microfinance clients who operate in various 
business sectors. One concern for targeting the microfinance users is that the take-up rate may have been artificially biased upward as the participation into training is obligatory or recommended. Another concern is that the microfinance users tend to be very small in size, typically employing only a few workers (McKenzie and Woodruff, 2012), while in reality, many SMEs in developing countries are of larger sizes, employing dozens of workers. Our sample enterprises are much larger in terms of employment than those of other studies, and this setting may offer a more realistic view of the potential of SMEs in developing countries.

Our contributions are as follows. Firstly, we find that the demand for these training programs by entrepreneurs was indeed low before the offer of training, possibly being a barrier to improve management, but it increased greatly with the participation experience of the relevant training programs. This suggests that these entrepreneurs' ex-ante demand was low because they had not known the significance of attending these training sessions. Participation in one kind of training also increased the demand for another type of training offered in future. Secondly, we confirmed that managerial capital is indeed transferrable via technical interventions, as shown in other existing studies. The training program had impacts on improving the business practices as well as business performance of participating enterprises. The on-site hands-on training customized to each workshop (hereinafter called onsite training) had a greater effect in improving business practices than the classroom lecture-type of training (hereinafter called classroom training), and there was also a synergy effect from participating in both types of trainings. Thirdly, the higher quantiles in the business practice score distribution were found to benefit more from the training. Lastly, we find that the willingness to learn prior to training has positive effects in enhancing the training 
impact on the business practice, particularly when it is combined with the own learning through classroom training participation.

In the next section, we illustrate our experimental setting and the data collected by our surveys. Section 3 presents the estimation methods, and section 4 explains the estimation results. The conclusion follows in section 5 .

\section{Experimental Setting and Data}

We implemented two types of training for the managers of the small and medium-sized enterprises in the knitwear industrial cluster in La Phu commune in Northern Vietnam, where many village-based industrial clusters are found (e.g., Vu et al., 2009, 2010). This cluster is located about $20 \mathrm{~km}$ from Hanoi, the capital of Vietnam. It has a long history of garment production, dating back before 1945 (Vu et al., 2010). Earlier many villagers from this cluster worked in French garment factories in Hanoi. In the 1960s, two state-owned enterprises (SOEs) were established near the village, producing towels and socks for export to the Soviet Union. In the 1970s, two cooperatives were established within the village, receiving subcontracting orders from these SOEs. When the Soviet Union collapsed in 1991, the SOEs stopped contracting out to these cooperatives, bringing closure to these cooperatives. The knitting machines used in the cooperatives were given to the member households, and this led to the expansion of household enterprises in this village. While these household enterprises sold to domestic market through petty traders in the beginning, many of them started exporting to Russia and Eastern Europe through the Vietkieu, overseas Vietnamese traders, who are originally from this village.

As of 2010, there were 161 enterprises that produce finished products, and most 
of them were engaged in knitwear clothing, such as sweaters, pants, and gloves. ${ }^{1}$ Within this village and nearby villages, there are numerous household enterprises specializing in fabricating and knitting parts of clothes, such as sleeves or collars, which sell to these finished-product enterprises, comprising a large knitting industry cluster. The majority of the proprietors of the finished-product companies used to be employed by the cooperatives or the SOEs and have the experience of working as household subcontractors before they established their companies (Vu et al., 2010). According to our data, about $22.5 \%$ of the enterprises export, while the others target the domestic market. Contracting-out and subcontracting-in some parts of the work is very common within the cluster. In 2011, $97.5 \%$ of the enterprises in La Phu contracted-out their work, while $27.5 \%$ subcontracted-in their work, because the majority of the subcontractors are located in the neighboring villages.

In the summer of 2010, we started a series of interventions to the enterprises in the cluster. Figure 1 describes the timeline of our activities. We conducted interviews with all of the 161 proprietors of the finished-product enterprises based on a questionnaire. Out of the 161, two enterprises were dropped from the sample because they were selected as "model enterprises" in the onsite training and received exceptionally-intensive treatment by the consultant team. The other 159 enterprises were interviewed in the baseline survey conducted before the classroom training, the first follow-up survey between the two training programs, and the second follow-up survey after the onsite training. All but one in the baseline survey sample answered our questionnaires in both the first and second follow-up survey, and the reason for this

\footnotetext{
${ }^{1}$ As there was no official list of these enterprises, we surveyed the leaders of all the residential blocks of the village to obtain the total number of enterprises.
} 
one enterprise's attrition was business closure. The survey included questions on the socio-economic characteristics of the owner and enterprise, business practices conducted, workers hired, finance, business performance, and the owners' willingness to pay to participate in the training programs.

Data on willingness-to-pay for the classroom training and the onsite training program were collected by using the dichotomous question separately for each program: "Would you pay 3 million VND (about 155USD as of 2010) to participate in the training program?"2 This is a hypothetical question, which is unaccompanied by any actual payment for a training fee and does not penalize respondents who give an affirmative answer without careful consideration. ${ }^{3}$ Thus, this question can lead to an exaggeration of the demand for training participation. In order to find a way to avoid such a bias in replies to hypothetical questions in general, Blumenschein et al. (2008) conducted laboratory experiments and found that the bias can be reduced to a negligible magnitude by means of what they call the "certainty approach." We employed this approach, which is the same in our context as asking, if the answer to the above willingness-to-pay question was positive, an additional question, "How sure are you about the answer?" with dichotomous options, "definitely sure," or "probably sure," and only count "definitely sure" as the affirmative answer. Although it would be desirable to obtain information on the shape of the demand curve, it is unknown whether the certainty approach can be used in sequence to elicit the willingness of the same respondent to pay different prices, without affecting the respondent's valuation. We

\footnotetext{
2 The amount $\$ 155$ was determined based on local information. Once the teaching materials are prepared and the training contents are standardized, it is not impossible to reduce the cost of the training program per participant to this level in future.

3 The willingness-to-pay question is hypothetical also in that when the question was asked of the training participants during the follow-up surveys, we asked whether they would pay 3 million VND to participate the training program if they had not received the training.
} 
confined ourselves to only one level of training fee. ${ }^{4}$

Another unique feature of our survey is the set of very detailed business practice questions related to business records, quality improvement, marketing strategy, and KAIZEN housekeeping practices, which will be explained below (see also Appendix). Whenever possible, our enumerators tried to verify the respondent's answers by inspecting the housekeeping arrangements in the workshop carefully and asking additional questions. This worked well in the case of such questions as "Do you keep raw materials and scraps separately?" It did not work if, for example, the respondent did not keep any records and when the question was "Do you separate household and business expenses?" Using the results of these structured interviews and observations, we constructed a business score index, which will be used to measure the performance of the enterprises. While we do not claim that this index is a perfect proxy of the quality of management, we believe it serves the purpose. Similar methods have been used in other studies (e.g., Bloom et al., 2011; de Mel et al., 2012).

After the baseline survey, we conducted the classroom lecture series, which lasted three weeks and was offered for two and a half hours in the evening to accommodate as many participants as possible. The topics were 1) Entrepreneurship, Business Strategy, and Marketing, 2) Production Management (including KAIZEN which is later explained), and 3) Accounting and Costing. The training was offered in a local language in a participatory manner, and participants were able to engage in the active discussions following the lectures.

Our second intervention was the tailor-made onsite consulting services offered at

\footnotetext{
4 This is what the authors of Blumenschein et al. (2008) recommended us to do in our personal communication with them.
} 
the workshop of each enterprise. The main purpose of the onsite training was to facilitate a better understanding on basic production management by giving specific advice to managers at their actual work space. Prior to the onsite training, two enterprises were selected to act as model enterprises, and the team of consultants designed improvement plans for the model enterprises, including such changes as labeling the tools and materials and changing the layout of the workshop, and actually applied the plans to the model enterprises. At the beginning of the onsite training, a seminar was held to explain the overall goal of the onsite training to the participants, and photographs of these model workshops before and after the application of the plans were also displayed. These model enterprises were also open to the participants afterwards for observation. The criteria for the selection of the model enterprises was that the model enterprises must be willing to share knowledge and experience with other participants and accept visitors to their workshops. Thus, the proprietors of the selected enterprises were more eager to learn about management and have larger workshops than average. The exclusion of these two enterprises from the sample would more likely lead to the underestimation of the impact of the training rather than overestimation. Each onsite training participant received visits from the consultant team twice. The first visit was to give advice based on the diagnosis of the current situation, and the second visit was to check on the progress and conduct follow-up. ${ }^{5}$

Both the classroom and onsite training were conducted by a team of local consultants and a Japanese consultant. The local consultant leader is a certified business consultant who is a Master Trainer of the International Labour Organization's Start and Improve Your Business (SIYB) program, which has been implemented

\footnotetext{
${ }^{5}$ For the details of the training, refer to Sonobe, Suzuki, and Otsuka (2010).
} 
worldwide. The main purpose of including a Japanese consultant was to transfer the knowledge of KAIZEN methods, a commonsense, inexpensive approach to management, which was developed on the basis of industrial engineering by incorporating the experiences and insights of Japanese manufacturing enterprises and is now commonly practiced in developed countries and emerging economies. The dispatched consultants were experts on KAIZEN and had considerable experience in KAIZEN training in Southeast Asia as well as in Japan. The local consultants were also able to learn from them for future use.

To conduct the experimental training, among the total 158 sample enterprises, we randomly selected 89 enterprises to invite to the classroom training program and 48 enterprises to invite to the onsite training programs, as shown in Table 1 . We refer to invitation as treatment in this table, so that the treatment group of the classroom training program consists of enterprises invited to this program, while the enterprises not invited to this program constitute the control group. There were 32 enterprises invited to both programs (Group 1) and 53 enterprises invited to neither program (Group 4). We deliberately invited more than half of the sample enterprises to the classroom training program taking account of the possibility of refusal to attend the training. Indeed 37 invited enterprises did not participate in the classroom training. By contrast, all the enterprises invited to the onsite training program participated in that program.

Table 2 presents the characteristics and business performances of each group observed during the baseline survey. The first two columns compare the treatment and control groups of the classroom training, and the $p$-values in column (3) indicate the statistical significance of the difference between the two groups. Columns (4) to (6) compare Group 1 and Group 2, while columns (7) to (9) compare Group 3 and Group 4. 
From these figures, we can see that the owners tend to be around forty years old, and about sixty percent of the owners are females, reflecting the fact that this is the fashion industry. Owners tend to have seven to eight years of education and have operated for about ten years. On average, they hired about 14.3 workers (permanent-worker equivalent) at the time of the baseline survey. ${ }^{6}$ This is worth emphasizing because most other studies of management training experiments focus on self-employed business persons or microenterprises with much smaller employment sizes.

Another important point is that despite the randomization, there are some statistically significant differences among the groups. This is because the sample size is small and because we divide the small sample into four groups, not just two. For example, while the treatment and control groups of the classroom training program do not differ significantly in the willingness-to-pay, significant differences emerge if we divide the sample into four groups. We will pay due consideration to this point when we assess the impacts of the training programs in the next two sections.

\section{Estimation Methods}

This paper presents the estimates of the intention-to-treat effects (ITT) and the treatment effect on the treated (TOT). The ITT estimates will show whether being invited to the training programs will enhance the outcomes, that is, willingness to pay, business practice score, and business performance, of those invited enterprises, while the TOT estimates will show the extent to which participating in the training programs will enhance the outcomes of the participants. The estimate of the ITT can be obtained by

\footnotetext{
${ }^{6}$ One seasonal worker is considered as one-third of a permanent worker based on the average number of months worked in a year by each type of worker.
} 
running the following regression:

$$
y_{i}=\alpha_{1} I_{i}^{B}+\alpha_{2} I_{i}^{C}+\alpha_{3} I_{i}^{O}+X_{i} \varphi+\varepsilon_{i},
$$

where $y_{i}$ is the outcome variable (i.e., either willingness-to-pay, business practice scores, or business performance) for enterprise $i$ after the onsite training program, $I_{i}^{j}$ is the invitation status dummy which is equal to 1 if enterprise $i$ was invited to the training program $j$ (= both, classroom, onsite) and 0 otherwise, and $X_{i}$ is a vector of variables representing the socio-economic characteristics of the business owner, which happened to be time-invariant in our sample, $\alpha$ 's are coefficients and $\varphi$ is a vector of coefficients, and $\varepsilon_{i}$ is an error term. If enterprise $i$ was invited to the classroom training program only, then $I_{i}^{C}=1$ and $I_{i}^{O}=I_{i}^{B}=0$. Likewise, if enterprise $i$ was invited to the onsite training program only, then $I_{i}^{O}=1$ and $I_{i}^{C}=I_{i}^{B}=0$. If enterprise $i$ was invited to both programs, the three invitation status dummies are equal to 1 . Thus, $I_{i}^{B}$ is the product of $I_{i}^{C}$ and $I_{i}^{O}$, and the impact of being invited to both programs is equal to $\alpha_{1}+\alpha_{2}+\alpha_{3}$.

The fixed-effect model corresponding to equation (1) may be written,

$$
y_{i t}=\beta_{1} I_{i}^{B} T_{t}^{O}+\beta_{2} I_{i}^{C} T_{t}^{O}+\beta_{3} I_{i}^{O} T_{t}^{O}+u_{i}+\lambda_{t}+w_{i t},
$$

where $y_{i t}$ is the outcome of enterprise $i$ at time $t$, which is before the classroom training program (i.e., at the time of the baseline survey) or after the onsite training program (i.e., at the time of the second follow-up survey), $T_{t}^{O}$ is a time dummy that equals 1 if $t$ is the time after the onsite training program (i.e., the time of the second follow-up survey) and 0 if $t$ is before the onsite training program (i.e., the time of the baseline survey), $\lambda_{t}$ is the time effect common to all the enterprises, $u_{i}$ is the fixed effect of enterprise $i$, and $w_{i t}$ is an error term. The effects of the time-invariant characteristics $X_{i}$ in equation (1) 
are superseded by the fixed effect $u_{i}$ in equation (2).

Coefficients $\beta$ 's in equation (2) capture the changes in the treatment group's outcome from the time of the baseline survey to the time of the second follow-up survey relative to the control group's counterpart. Coefficients $\alpha$ 's in equation (1) capture the difference in the level between the groups at the time of the second follow-up survey, which amounts to the difference in the initial level plus the difference in the changes. If randomization were perfect, there would be no difference in the initial level and, hence, the estimates of $\alpha$ 's would be close to the estimates of $\beta$ 's, even though the estimation of equation (1) uses only the second follow-up survey data while the estimation of equation (2) uses both the baseline data and the second follow-up survey data. As we have seen from Table 2, however, it happened to be that, at the time of the baseline survey, those enterprises which were invited only to the onsite training program (i.e., Group 3) were already more willing to pay for the classroom training than those who were invited to neither program (i.e., Group 4). Thus, the estimate of $\alpha_{3}$ is expected to be greater than the estimate of $\beta_{3}$ in the regressions of the willingness to pay for the classroom training.

Another version of the fixed-effects model may be written

$$
\begin{aligned}
y_{i t} & =\gamma_{1} I_{i}^{B} T_{t}^{C}+\gamma_{2} I_{i}^{B} T_{t}^{O}+\gamma_{3} I_{i}^{C} T_{t}^{C}+\gamma_{4} I_{i}^{C} T_{t}^{O}+\gamma_{5} I_{i}^{O} T_{t}^{C}+\gamma_{6} I_{i}^{O} T_{t}^{O} \\
& +u_{i}+\lambda_{t}+\varepsilon_{i t},
\end{aligned}
$$

where subscript $t$ indicates the time of either the baseline survey, the first follow-up survey, or the second follow-up survey, $T_{t}^{C}$ is a time dummy equal to 1 if $t$ is the time after the classroom training program (i.e., the time of the first or the second follow-up survey). The estimation of this fixed-effects model is expected to reveal the timing of 
when each group felt the impacts of the interventions. For example, suppose that Group 2 increases their willingness-to-pay for the classroom training after the classroom training program relative to the control group and further increases it after the onsite training program. In this case, both $\gamma_{3}$ and $\gamma_{4}$ will be positive, and the combined effect $\gamma_{3}+\gamma_{4}$ should be equal to the training effect on the willingness-to-pay measured after the onsite training, i.e., $\beta_{2}$ in equation (2). Likewise, $\gamma_{1}+\gamma_{2}$ should be equal to $\beta_{1}$, and $\gamma_{5}+\gamma_{6}$ should be equal to $\beta_{3} .^{7}$

We turn now to our method for estimating the TOT. The equations to be estimated are similar to equations (1) to (3), but they feature the participation status dummies $P$ 's instead of the invitation status dummies I's. As we saw in Table 1, a number of the enterprises that were invited to the classroom training program did not participate in it. Hence, $P_{i}^{C}$ is not equal to $I_{i}^{C}$, and it is not exogenous like $I_{i}^{C}$ but self-selected. Likewise the interaction terms $P_{i}^{C} T_{t}^{C}$ and $P_{i}^{C} T_{t}^{O}$, the counterparts of $I_{i}^{C} T_{t}^{C}$ and $I_{i}^{C} T_{t}^{O}$ in equation (2) or (3), are endogenous. By contrast, $P_{i}^{O}$ is equal to $I_{i}^{O}$ for all $i$ because in the case of the onsite training, every sample enterprise complied with the random assignment to the treatment or control group. It should be clear, however, that $P_{i}^{B}$, the dummy indicating whether enterprise $i$ participated in both programs, is endogenous, and so are the interaction terms that include $P_{i}^{B}$. To mitigate the estimation-bias problem arising from the self-selection into participation in the classroom training program, we apply the instrumental variable method to the endogeneity of $P_{i}^{C}, P_{i}^{B}$, and the interaction terms of these dummies and time dummies. Our instrumental variables are $I_{i}^{C}, I_{i}^{B}$, and the corresponding interaction terms, which

\footnotetext{
${ }^{7}$ If our data are of unbalanced panel, however, these equalities do not hold true.
} 
should be valid instrumental variables because they are closely associated with the corresponding endogenous variables but exogenous to the outcomes.

We use equations (1) to (3) and their IV counterparts to estimate the ITT and TOT on the willingness-to-pay, the business practice score, and business performance. In addition, we estimate the quantile treatment effect on the business practice score, that is, the impacts of the training on the distribution of the business practice score, not just its means. Examining the difference of training impact across the distribution may provide additional information useful for designing a more effective training program. Suppose, for example, that the training increases the business practice scores of only those participants whose baseline scores were relatively high. It is advisable to revise the training contents so that they can be understood and adopted by a greater number of participants. Conversely, if the training is found to benefit only the participants with relatively low initial scores, it suggests the need for providing a more advanced course for those with relatively high initial scores.

We estimate the quantile treatment effects of the classroom and onsite training programs. For the classroom training program, we employ the unconditional endogenous quantile regression estimator developed by Frölich and Melly (2010). For the onsite training program, however, we employ the unconditional exogenous quantile regression estimator developed by Firpo (2007) because all the invited enterprises participated in the onsite training but not in the classroom training. Frölich and Melly (2010) show that unlike the mean treatment effect, estimated quantile treatment effects are asymptotically affected by the inclusion of covariates even when the covariates are independent from the treatment status. In their method, the covariates are excluded from the final regression equation but included in the first stage 
regression. ${ }^{8}$

Before closing this section, we would like to add that there may be spillovers of training effects from the participants to the non-participants because of the strong social connection in the cluster. What are estimated by means of the above specifications may be the extra effects of family networks over and above social networks. As such, the estimated training effects might be expected to be biased downward.

\section{Estimation Results}

Since the take-up rate for the invitation to classroom training was low (Table 1), we begin by examining who actually participated in the classroom training. The estimates of the probit models are shown in Table 3. Three explanatory variables, i.e., the age, sex, and initial business practice score of the business owner, are statistically significant, indicating that among the invited entrepreneurs, those who accepted the invitation tended to be young males and have relatively high initial business practice scores. As shown in Table 1 , the take-up rate for onsite training improved dramatically to $100 \%$ compared to the take-up rate for classroom training. This increase might have occurred because of the lower opportunity costs or higher perceived benefit of the onsite training relative to the classroom training, or because they came to value managerial training in general more than before the classroom training program.

Tables 4 and 5 present the estimated ITT and TOT, respectively, of the classroom and onsite training programs on the willingness-to-pay for each training program. Columns (i) to (iii) show the estimated impacts on the willingness-to-pay for the classroom training, while columns (iv) to (vi) show those for the onsite training.

\footnotetext{
8 The conditional endogenous quantile effects estimation was developed by Abadie, Angrist, and Imbens (2002). We used the conditional endogenous quantile effects estimator as well and found that the results are qualitatively the same as Figure 2.
} 
Columns (i) and (iv) report the OLS estimates of equation (1) discussed in the previous section, while columns (ii) and (v) report the estimated fixed-effects model in equation (2) and columns (iii) and (vi) to the fixed-effects model in equation (3).

In column (i) of Table 4, the coefficient on the Class Invite dummy is positive and significant. This result is reinforced by the positive and significant coefficient on the interaction term Class Invite $\times T_{\text {onsite }}$ in column (ii) as well as those on the interaction terms Both Invite $\times T_{\text {class }}$ and Class Invite $\times T_{\text {class }}$ in column (iii). These results are consistent with our expectation that the training program increases the willingness to pay. Although the OLS estimate of the coefficient on Onsite Invite dummy is positive and significant in column (i), its fixed-effect counterparts, i.e., the coefficients on Onsite Invite $\times T_{\text {onsite }}$ in columns (ii) and (iii) are insignificant. These results indicate that while Group 3 is more willing to pay for the classroom training than Group 4, this is not a result of the training that Group 3 received. Presumably this is because Group 3 happened to include those business owners who were willing to pay for the classroom training from the beginning, as we saw in Table 2.

In column (iv), the coefficients on the Both Invite dummy and the Onsite Invite dummy are positive and significant. Consistently, the coefficient on the interaction term Both Invite $\times T_{\text {onsite }}$ is positive and significant in columns (v) and (vi), and so is the coefficient on Onsite Invite $\times T_{\text {onsite }}$ in column $(\mathrm{v})$. These results indicate that the willingness-to-pay of Groups 1 and 3 for the onsite training increased after the onsite training program.

Table 5 reports the estimates of the TOT impacts of the two training programs on the willingness-to-pay for each program. To mitigate the estimation bias due to the self-selection into participation, the explanatory variables are instrumented with the 
corresponding invitation status. The estimates shown in Table 5 are qualitatively similar to those in Table 4. Overall, the regression results shown in Tables 4 and 5 lend strong support to our hypotheses that small business owners are unaware of the value of learning about basic management practices, and that participation in even a short-term training course like ours can help them appreciate the value of improving managerial skills.

In order to assess the impact of training on the business practices, we listed 30 basic business practices, and during each survey, we counted how many of the 30 practices each sample enterprise had adopted by the time of the survey. Before examining the changes in these scores due to participation, we examined the association between the initial business practice score and the initial business performance in terms of the revenue, value added, and profit in 2009. The results are shown in Table 6. The business score is positively associated with these indicators of business performance at the 1 percent level of statistical significance, even though this table is purely descriptive and not intended to show the causal relationship. This exercise is intended only to see if the impacts of the training programs on this business score are worth exploring below.

Note, however, that the two rounds of follow-up survey were conducted too soon after the intervention for the post-training performance of the training participants to be reflected in their revenues, value added, or profits. Thus, we explore only the impacts of the training programs on the business score, as shown in the first three columns in Tables 7 and 8, and the impacts on the logarithm of material costs in the last two columns. Compared with sales revenues, value added, and profit, material costs may quickly reflect improvement in managerial skills or in business practices. We have to 
admit that such improvement can theoretically increase or decrease material costs. While better production management will reduce wasteful uses of materials, the improved efficiency may lead to the expansion of production, which may in turn require a greater input of materials in the long run. In view of the fact that the follow-up surveys were conducted soon after the training programs were completed, we expect that our data reflect the cost reduction effect of improved management.

Tables 7 and 8 report the ITT impacts and TOT impacts, respectively, of the training programs on the business score and material cost. The design of the first three columns in these tables is the same as that in Tables 4 and 5. ${ }^{9}$ According to column (iii) of Table 7, the invitation to the classroom training increased the business score by 1.28 points (out of 30 points) for Group 2 and by $1.28+1.13$ points for Group 1 , while the invitation to the onsite training program increased the score by 3.84 points for Group 3 and by $3.84+0.35$ points for Group 1, compared with Group 4. The TOT counterparts of these impacts on the business scores are stronger for Groups 1 and 2, as shown in Table 8.

The results of the regressions of material costs are somewhat mixed. As shown in column (iv) of Tables 7 and 8, the impacts of the two training programs on material costs are insignificant if they are estimated by means of the second follow-up survey only. As shown in column (v), however, the impact of the onsite training program is negative and significant, if it is estimated by means of the fixed-effects estimator or the fixed-effects IV estimator. The result that the impact of the onsite training was stronger than the impact of the classroom training is consistent with the fact that the

\footnotetext{
${ }^{9}$ Our panel data are no longer balanced because we failed to collect data on the business score and material costs from some enterprises. For this reason, the relationships among coefficients mentioned in the previous section, such as $\gamma_{1}+\gamma_{2}=\beta_{1}$, do not hold true in Table 7 and 8 .
} 
onsite training was centered around KAIZEN, which emphasizes the reduction of wasteful uses of materials, time, and other resources.

Apart from the business practice score, we also elicited directly from the participants whether they adopted any practices that they had learnt from the training program. Table 9 reports the estimated linear probability models explaining the presence or absence of such adoption of practices, using the sample of participants only. Columns (i) and (ii) concern the adoption behaviors of the classroom training participants. While the willingness-to-pay is included in column (i), it is not in column (ii) to avoid the estimation bias problem due to the possible endogeneity of the willingness-to-pay. Similarly, columns (iii) and (iv) are intended to examine the adoption behaviors of the onsite training participants, and their willingness-to-pay is included in column (iii) but not in column (iv).

In columns (i) and (ii), no coefficient is significant, indicating that no characteristics affect the adoption behavior of the participants in the classroom training program. By contrast, among the onsite training participants, the adoption of any practices that were taught during the onsite training program is associated negatively with their education levels and positively with their initial willingness-to-pay, and to a lesser extent with their initial business scores. Thus, the practices taught in the onsite training program may not be new to educated business owners, but they are worthwhile for less educated owners and tended to be adopted by those who had the will to learn about management. This result points to the importance of raising the valuation of trainings by participants before intervention as it would lead to better results.

The results of the quantile treatment regressions are shown in the two panels of Figure 2. We find that the magnitude of the treatment effect on the business score 
generally increases with the quantile of the initial business score. This trend holds true for both classroom training and onsite training. Assuming that rank reversals in the business practice distribution are not common, this result suggests that those business owners with higher business scores generally benefit more from the training that they receive. A possible interpretation is that the contents taught in our training programs were not too easy and required some degree of prior experience or knowledge to put into practice the lessons learnt.

\section{Conclusion}

In this paper, we have examined experimentally the impacts of managerial training programs undertaken in a classroom and on site. Our first finding is that the demand for these training programs by the entrepreneurs prior to the offer of the trainings was indeed low, but it increased greatly with own experience of participation. This lack of knowledge about the value of training may have been a barrier to business improvement. Although we did not test for other potential reasons mentioned in the introduction (credit constraints, supply-side constraints, positive spillovers), credit constraints were unlikely to be an important reason because all the entrepreneurs in our sample have owned assets that could be used as collateral, such as residential houses, workshop buildings, storehouses, sewing machines, knitting machines, motorcycles, and yarn and other intermediate inputs. Rather, the concept of receiving management training in order to improve their business performance was new to them and, thus, they did not have any clear idea about where they could have received proper training, according to our interviews with them. We also find that the ex-ante higher demand for training enhances the positive training impacts on the performance. This finding supports the 
importance of raising the awareness of the value of learning prior to training interventions.

Secondly, we find that the managerial training did indeed improve the business practices and the financial performances of participating firms. The impact on business practice scores was greater for the onsite training than for the classroom training and there was also a compounding effect from participating in both trainings. Thirdly, examining the distribution of the training effect, we find that both classroom and on-site training programs were more beneficial for those at the higher quantiles. These findings have immediate policy implications for the government or development aid agencies when they design training programs for SME managers in future. 


\section{References}

Abadie, Alberto, Angrist, Joshua, Imbens, Guido, 2002. Instrumental variables estimates of the effect of subsidized training on the quantiles of trainee earnings. Econometrica 70(1), 91-117.

Bandiera, Oriana, Rasul, Imran, 2006. Social networks and technology adoption in northern Mozambique. Economic Journal 116(October), 869-902.

Bloom, Nicholas, Eifert, Benn, Mahajan, Aprajit, McKenzie, David, Roberts, John, 2011. Does management matter? Evidence from India. Working Paper No. 16658. NBER, Cambridge, MA.

Blumenschein, Karen, Blomquist, Glenn C., Johannesson, Magnus, Horn, Nancy, Freeman, Patricia, 2008. Eliciting willingness to pay without bias: Evidence from a field experiment. Economic Journal 118(January), 114-137.

Bruhn, Miriam, Karlan, Dean, Schoar, Antoinette, 2010. What capital is missing in developing countries? American Economic Review Papers and Proceedings 100(2), $629-633$

Conley, Timothy, Udry, Christopher, 2010. Learning about a new technology: Pineapple in Ghana. American Economic Review 100(1), 35-69.

De Mel, Suresh, McKenzie, David, Woodruff, Christopher, 2012. Business training and female enterprise start-up, growth, and dynamics: Experimental evidence from Sri Lanka. Policy Research Working Paper 6145. World Bank, Washington D.C..

Drexler, Alejandro, Fischer, Greg, Schoar, Antoinette S., 2010. Keeping it simple: Financial literacy and rules of thumb. Discussion Paper No. 7994, Centre for Economic Policy Research, London.

Duflo, Esther, Glennerster, Rachel, Kremer, Michael, 2008. Chapter 61 Using 
randomization in development economics research: A toolkit. In: Schultz, T. Paul, Strauss, John (Eds.), The Handbook of Development Economics, Vol. 4. Elsevier, Amsterdam, pp. 3895-3961.

Duflo, Ester, Kremer, Michael, Robinson, Jonathan, 2008. How high are rates of return to fertilizer? Evidence from field experiments in Kenya. American Economic Review: Papers \& Proceedings 98(2), 482-488.

Firpo, Sergio, 2007. Efficient semiparametric estimation of quantile treatment effects. Econometrica 75, 259-276.

Frölich, Markus, Melly, Blaise, 2010. Estimation of quantile treatment effects with Stata. The Stata Journal 10(3), 423-457.

Ichino, Nahomi, Schündeln, Matthias, 2012. Deterring or displacing electoral irregularities? Spillover effects of observers in a randomized field experiment in Ghana. Journal of Politics 74(1), 292-307.

Karlan, Dean, Valdivia, Martin, 2011. Teaching entrepreneurship: Impact of business training on microfinance clients and institutions. Review of Economics and Statistics 93(2), 510-27.

Mano, Yukichi, Iddrisu, Alhassan, Yoshino, Yutaka, Sonobe, Tetsushi, 2012. How can micro and small enterprises in Sub-Saharan Africa become more productive? The impacts of experimental basic managerial training. World Development 40(3), 458-68.

Marshall, Alfred, 1920. Principles of Economics. Palgrave Macmillan, London.

Matuschke, Ira, Qaim, Martin, 2009. The impact of social networks on hybrid seed adoption in India. Agricultural Economics 40, 493-505.

McKenzie, David, Woodruff, Christopher, 2012. What are we learning from business 
training and entrepreneurship evaluations around the developing world? Policy Research Working Paper 6202. World Bank, Washington D.C..

Miguel, Edward, Kremer, Michael, 2004. Worms: Identifying impacts on education and health in the presence of treatment externalities. Econometrica 72 (1), 159-217.

Rubin, Donald B., 1978. Bayesian inference for causal effects: The role of randomization. Annals of Statistics 6, 34-48.

Sonobe, Tetsushi, Suzuki, Aya, Otsuka, Keijiro, 2011. Kaizen for managerial skills improvement in small and medium enterprises: An impact evaluation study. World Bank, Washington D.C.

Vu, Hoang N., Sonobe, Tetsushi, Otsuka, Keijiro, 2009. An inquiry into the transformation process of village-based industrial clusters: The case of an iron and steel cluster in northern Vietnam. Journal of Comparative Economics 37(4), $568-581$.

Vu, Hoang N., Sonobe, Tetsushi, Otsuka, Keijiro, 2010. An inquiry into the development process of village industries: The case of a knitwear cluster in northern Vietnam. Journal of Development Studies 46(2), 312-330. 
Table 1: Sample Size by Group

\begin{tabular}{|c|c|c|c|c|}
\hline & \multicolumn{2}{|c|}{ Classroom Training } & \multirow[b]{2}{*}{ Total } \\
\hline & & Treatment Group & Control Group & \\
\hline \multirow{2}{*}{ 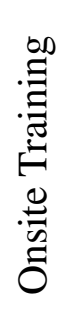 } & $\begin{array}{c}\text { Treatment } \\
\text { Group }\end{array}$ & $\begin{array}{c}\text { Group } 1 \\
32\end{array}$ & $\begin{array}{c}\text { Group } \\
16\end{array}$ & $\begin{array}{c}\text { Onsite treatment } \\
48 \\
\text { (Refused: } 0 \text { ) }\end{array}$ \\
\hline & $\begin{array}{l}\text { Control } \\
\text { Group }\end{array}$ & $\begin{array}{c}\text { Group } 2 \\
57\end{array}$ & $\begin{array}{c}\text { Group } 4 \\
53\end{array}$ & $\begin{array}{l}\text { Onsite control } \\
110\end{array}$ \\
\hline & Total & $\begin{array}{c}\text { Classroom treatment } \\
89 \\
\text { (Refused: } 37 \text { ) }\end{array}$ & $\begin{array}{c}\text { Classroom control } \\
69\end{array}$ & 158 \\
\hline
\end{tabular}


Table 2: Mean Characteristics Prior to the Intervention by Treatment Status

\begin{tabular}{|c|c|c|c|c|c|c|c|c|c|}
\hline & $\begin{array}{l}\text { Groups } 1 \& 2 \\
\text { Invited to } \\
\text { classroom } \\
\text { training } \\
\text { (1) }\end{array}$ & $\begin{array}{l}\text { Groups } 3 \& 4 \\
\text { Uninvited to } \\
\text { classroom } \\
\text { training } \\
\text { (2) }\end{array}$ & $\begin{array}{c}p \text {-value } \\
\text { for } \mathrm{H}_{0} \text { : } \\
(1)=(2) \\
(3)\end{array}$ & $\begin{array}{l}\text { Group } 1 \\
\text { Invited to } \\
\text { both } \\
\text { programs } \\
\quad(4)\end{array}$ & $\begin{array}{c}\text { Group } 2 \\
\text { Invited only } \\
\text { to classroom } \\
\text { training } \\
(5)\end{array}$ & $\begin{array}{c}p \text {-value } \\
\text { for } \mathrm{H}_{0} \text { : } \\
(4)=(5) \\
(6)\end{array}$ & $\begin{array}{c}\text { Group } 3 \\
\text { Invited only } \\
\text { to onsite } \\
\text { training } \\
(7)\end{array}$ & $\begin{array}{l}\text { Group } 4 \\
\text { Invited to } \\
\text { neither } \\
\text { program } \\
\quad(8)\end{array}$ & $\begin{array}{c}p \text {-value } \\
\text { for } \mathrm{H}_{0} \text { : } \\
(7)=(8) \\
(9)\end{array}$ \\
\hline Owner's age & $\begin{array}{c}40.9 \\
(8.92)\end{array}$ & $\begin{array}{c}40.8 \\
(10.64)\end{array}$ & [0.93] & $\begin{array}{c}40.4 \\
(7.91)\end{array}$ & $\begin{array}{c}41.2 \\
(9.50)\end{array}$ & [0.68] & $\begin{array}{c}39.3 \\
(8.56)\end{array}$ & $\begin{array}{l}41.4 \\
(11.2\end{array}$ & [0.49] \\
\hline Male owner $(\%)$ & $\begin{array}{c}36.0 \\
(48.26)\end{array}$ & $\begin{array}{c}37.1 \\
(48.67)\end{array}$ & {$[0.88]$} & $\begin{array}{c}25.0 \\
(43.99)\end{array}$ & $\begin{array}{c}42.1 \\
(49.81)\end{array}$ & {$[0.11]$} & $\begin{array}{c}43.8 \\
(51.23)\end{array}$ & $\begin{array}{c}34.0 \\
(47.81)\end{array}$ & {$[0.48]$} \\
\hline Owner's education (years) & $\begin{array}{c}7.9 \\
(2.66)\end{array}$ & $\begin{array}{c}8.5 \\
(3.23)\end{array}$ & {$[0.18]$} & $\begin{array}{c}7.8 \\
(2.27)\end{array}$ & $\begin{array}{c}8.0 \\
(2.88)\end{array}$ & {$[0.70]$} & $\begin{array}{c}8.6 \\
(3.40)\end{array}$ & $\begin{array}{c}8.5 \\
(3.24)\end{array}$ & [0.89] \\
\hline Years of operation & $\begin{array}{c}10.2 \\
(4.60)\end{array}$ & $\begin{array}{c}9.5 \\
(4.81)\end{array}$ & {$[0.39]$} & $\begin{array}{c}10.7 \\
(4.80)\end{array}$ & $\begin{array}{c}9.9 \\
(4.51)\end{array}$ & {$[0.47]$} & $\begin{array}{c}9.8 \\
(4.15)\end{array}$ & $\begin{array}{c}9.5 \\
(5.01)\end{array}$ & {$[0.84]$} \\
\hline Training experience $(\%)$ & $\begin{array}{c}13.5 \\
(34.35)\end{array}$ & $\begin{array}{c}10.3 \\
(30.61)\end{array}$ & {$[0.55]$} & $\begin{array}{c}12.5 \\
(33.6)\end{array}$ & $\begin{array}{c}14.0 \\
(35.0)\end{array}$ & {$[0.84]$} & $\begin{array}{c}25.0 \\
(44.7)\end{array}$ & $\begin{array}{c}5.9 \\
(23.76)\end{array}$ & {$[0.03]$} \\
\hline Relatives abroad (\#) & $\begin{array}{c}0.1 \\
(0.53)\end{array}$ & $\begin{array}{c}0.3 \\
(0.91)\end{array}$ & {$[0.12]$} & $\begin{array}{c}0.1 \\
(0.71)\end{array}$ & $\begin{array}{c}0.1 \\
(0.40)\end{array}$ & {$[0.54]$} & $\begin{array}{c}0.1 \\
(0.50)\end{array}$ & $\begin{array}{c}0.3 \\
(1.01)\end{array}$ & {$[0.50]$} \\
\hline Relatives in the sample (\#) & $\begin{array}{c}1.3 \\
(1.87)\end{array}$ & $\begin{array}{c}0.8 \\
(1.61)\end{array}$ & {$[0.12]$} & $\begin{array}{c}2.1 \\
(2.03)\end{array}$ & $\begin{array}{c}0.8 \\
(1.63)\end{array}$ & {$[0.00]$} & $\begin{array}{c}0.5 \\
(0.82)\end{array}$ & $\begin{array}{c}0.92 \\
(1.79)\end{array}$ & {$[0.36]$} \\
\hline Perm workers (\#) & $\begin{array}{c}9.2 \\
(10.01)\end{array}$ & $\begin{array}{c}19.0 \\
(39.70)\end{array}$ & {$[0.03]$} & $\begin{array}{c}8.5 \\
(4.92)\end{array}$ & $\begin{array}{c}9.6 \\
(11.99)\end{array}$ & {$[0.60]$} & $\begin{array}{c}26 \\
(44.14)\end{array}$ & $\begin{array}{c}17.2 \\
(38.82)\end{array}$ & {$[0.45]$} \\
\hline Seasonal workers (\#) & $\begin{array}{c}4.1 \\
(6.50)\end{array}$ & $\begin{array}{c}5.8 \\
(9.86)\end{array}$ & {$[0.21]$} & $\begin{array}{c}5.2 \\
(9.02)\end{array}$ & $\begin{array}{c}3.5 \\
(4.51)\end{array}$ & {$[0.24]$} & $\begin{array}{c}8.1 \\
(13.06)\end{array}$ & $\begin{array}{c}5.2 \\
(8.78)\end{array}$ & {$[0.31]$} \\
\hline Revenue ('09, USD) & $\begin{array}{c}194397 \\
(194996)\end{array}$ & $\begin{array}{c}283683 \\
(415166)\end{array}$ & {$[0.08]$} & $\begin{array}{c}239808 \\
(203467)\end{array}$ & $\begin{array}{c}168903 \\
(187067)\end{array}$ & {$[0.10]$} & $\begin{array}{c}346680 \\
(449209)\end{array}$ & $\begin{array}{c}267874 \\
(410232)\end{array}$ & {$[0.51]$} \\
\hline VA ('09, USD) & $\begin{array}{c}59367 \\
(93910)\end{array}$ & $\begin{array}{c}81400 \\
(169585)\end{array}$ & {$[0.30]$} & $\begin{array}{c}67756 \\
(93626)\end{array}$ & $\begin{array}{c}54657 \\
(94569)\end{array}$ & {$[0.53]$} & $\begin{array}{c}90504 \\
(165583)\end{array}$ & $\begin{array}{c}79619 \\
(173773)\end{array}$ & {$[0.83]$} \\
\hline Willingness-to-pay for: & & & & & & & & & \\
\hline Classroom training $(\%)$ & $\begin{array}{c}20.2 \\
(40.4)\end{array}$ & $\begin{array}{c}14.3 \\
(35.2)\end{array}$ & {$[0.33]$} & $\begin{array}{c}28.1 \\
(45.7))\end{array}$ & $\begin{array}{c}15.8 \\
(36.8)\end{array}$ & {$[0.17]$} & $\begin{array}{c}37.5 \\
(50.0)\end{array}$ & $\begin{array}{c}7.5 \\
(26.7)\end{array}$ & {$[0.00]$} \\
\hline Onsite training $(\%)$ & $\begin{array}{c}5.6 \\
(23.2)\end{array}$ & $\begin{array}{c}8.6 \\
(28.2)\end{array}$ & {$[0.47]$} & $\begin{array}{c}15.6 \\
(36.9)\end{array}$ & $\begin{array}{c}0 \\
(0)\end{array}$ & {$[0.00]$} & $\begin{array}{c}25.0 \\
(44.7)\end{array}$ & $\begin{array}{c}3.8 \\
(19.2)\end{array}$ & {$[0.01]$} \\
\hline
\end{tabular}

Note) Standard deviations are reported in parentheses. 
Table 3: Determinants of Classroom Training Participation (Probit, ME)

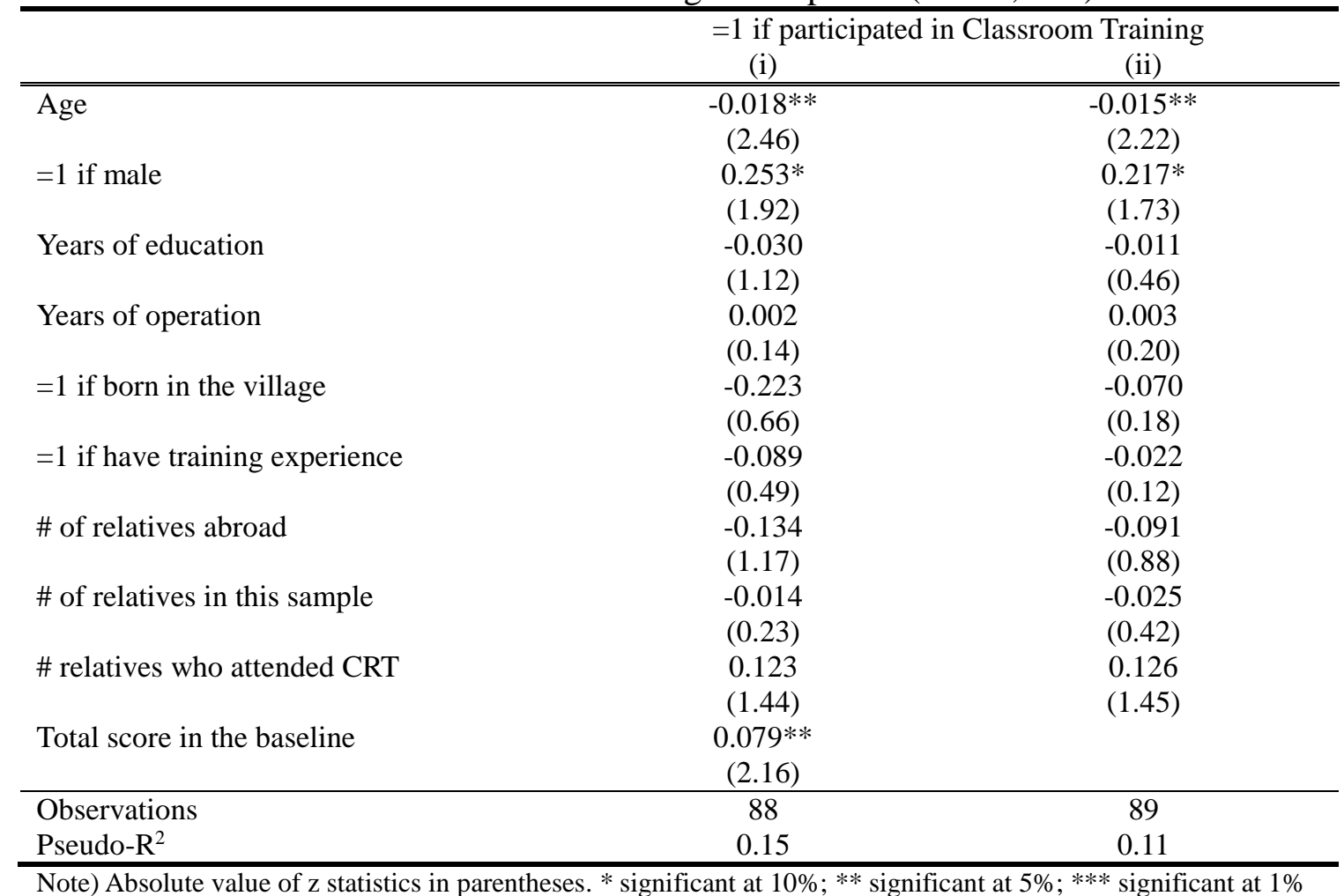


Table 4: ITT Impacts of Training on Willingness-to-Pay

\begin{tabular}{|c|c|c|c|c|c|c|}
\hline & \multicolumn{3}{|c|}{ WTP for Classroom Training } & \multicolumn{3}{|c|}{ WTP for Onsite Training } \\
\hline & $\begin{array}{l}\text { Cross } \\
\text { section }\end{array}$ & Panel & Panel & $\begin{array}{l}\text { Cross } \\
\text { section }\end{array}$ & Panel & Panel \\
\hline & $\begin{array}{l}\text { OLS } \\
\text { (i) }\end{array}$ & $\begin{array}{l}\mathrm{FE} \\
\text { (ii) }\end{array}$ & $\begin{array}{l}\mathrm{FE} \\
\text { (iii) }\end{array}$ & $\begin{array}{l}\text { OLS } \\
\text { (iv) }\end{array}$ & $\begin{array}{l}\mathrm{FE} \\
\text { (v) }\end{array}$ & $\begin{array}{l}\mathrm{FE} \\
(\mathrm{vi})\end{array}$ \\
\hline Both Invite & $\begin{array}{l}-0.019 \\
(0.12)\end{array}$ & & & $\begin{array}{c}0.384 * * * \\
(2.72)\end{array}$ & & \\
\hline Class Invite & $\begin{array}{c}0.259^{* * *} \\
(3.21)\end{array}$ & & & $\begin{array}{l}-0.023 \\
(0.76)\end{array}$ & & \\
\hline Onsite Invite & $\begin{array}{c}0.334 * * \\
(2.59)\end{array}$ & & & $\begin{array}{c}0.325 * * * \\
(2.87)\end{array}$ & & \\
\hline Both Invite $\times$ Tclass & & & $\begin{array}{c}0.216^{* *} \\
(2.01)\end{array}$ & & & $\begin{array}{l}0.012 \\
(0.34)\end{array}$ \\
\hline Both Invite $\times$ Tonsite & & $\begin{array}{l}0.202 \\
(1.64)\end{array}$ & $\begin{array}{l}-0.014 \\
(0.19)\end{array}$ & & $\begin{array}{c}0.401 * * * \\
(3.22)\end{array}$ & $\begin{array}{c}0.389 * * * \\
(3.15)\end{array}$ \\
\hline Class Invite $\times$ Tclass & & & $\begin{array}{c}0.190 * * * \\
(3.06)\end{array}$ & & & $\begin{array}{l}0.019 \\
(1.00)\end{array}$ \\
\hline Class Invite $\times$ Tonsite & & $\begin{array}{c}0.173 * * * \\
(2.85)\end{array}$ & $\begin{array}{l}-0.018 \\
(1.00)\end{array}$ & & $\begin{array}{l}0.036 \\
(1.41)\end{array}$ & $\begin{array}{l}0.018 \\
(1.00)\end{array}$ \\
\hline Onsite Invite $\times$ Tclass & & & $\begin{array}{l}-0.038 \\
(1.42)\end{array}$ & & & $\begin{array}{l}0.019 \\
(1.00)\end{array}$ \\
\hline Onsite Invite $\times$ Tonsite & & $\begin{array}{l}0.025 \\
(0.37)\end{array}$ & $\begin{array}{l}0.062 \\
(1.02)\end{array}$ & & $\begin{array}{c}0.144 * \\
(1.68)\end{array}$ & $\begin{array}{l}0.125 \\
(1.49)\end{array}$ \\
\hline Tclass & & & $\begin{array}{l}0.038 \\
(1.42)\end{array}$ & & & $\begin{array}{r}-0.019 \\
(1.00)\end{array}$ \\
\hline Tonsite & & $\begin{array}{l}0.038 \\
(1.43)\end{array}$ & $\begin{array}{l}0.000 \\
(0.01)\end{array}$ & & $\begin{array}{l}-0.019 \\
(1.00)\end{array}$ & $\begin{array}{c}-0.000 \\
(0.01)\end{array}$ \\
\hline Age & $\begin{array}{l}-0.004 \\
(1.03)\end{array}$ & & & $\begin{array}{l}0.001 \\
(0.27)\end{array}$ & & \\
\hline$=1$ if male & $\begin{array}{l}0.054 \\
(0.75)\end{array}$ & & & $\begin{array}{l}0.025 \\
(0.50)\end{array}$ & & \\
\hline Years of education & $\begin{array}{l}0.001 \\
(0.07)\end{array}$ & & & $\begin{array}{l}0.014 \\
(1.59)\end{array}$ & & \\
\hline$=1$ if born in the village & $\begin{array}{c}0.225^{* *} \\
(2.10)\end{array}$ & & & $\begin{array}{l}0.097 \\
(1.22)\end{array}$ & & \\
\hline Years of operation & $\begin{array}{l}-0.004 \\
(0.49)\end{array}$ & & & $\begin{array}{c}-0.011^{* *} \\
(2.07)\end{array}$ & & \\
\hline \# relatives abroad & $\begin{array}{l}-0.013 \\
(0.22)\end{array}$ & & & $\begin{array}{c}-0.059^{*} \\
(1.75)\end{array}$ & & \\
\hline$=1$ if training experience & $\begin{array}{l}0.012 \\
(0.10)\end{array}$ & & & $\begin{array}{l}0.094 \\
(1.41)\end{array}$ & & \\
\hline \# relatives in this sample & $\begin{array}{l}0.031 \\
(1.29)\end{array}$ & & & $\begin{array}{l}0.008 \\
(0.71)\end{array}$ & & \\
\hline Constant & $\begin{array}{l}0.050 \\
(0.21)\end{array}$ & $\begin{array}{c}0.177 * * * \\
(12.34)\end{array}$ & $\begin{array}{c}0.177 * * * \\
(9.47)\end{array}$ & $\begin{array}{l}-0.114 \\
(0.67)\end{array}$ & $\begin{array}{c}0.070 * * * \\
(6.40)\end{array}$ & $\begin{array}{c}0.070 * * * \\
(8.06)\end{array}$ \\
\hline Observations & 156 & 316 & 474 & 156 & 316 & 474 \\
\hline Number of ID & 156 & 158 & 158 & 156 & 158 & 158 \\
\hline$R$-squared & 0.25 & 0.30 & 0.29 & 0.55 & 0.47 & 0.45 \\
\hline Prob $>F($ or chi 2$)$ & 0.00 & 0.00 & & 0.00 & 0.00 & \\
\hline
\end{tabular}

Note) Robust t statistics in parentheses (clustered s.e. at ID level for ITT). * significant at 10\%; ** significant at 5\%; $* * *$ significant at $1 \%$. Variables with + are instrumented with random invitation status. 
Table 5: TOT Impacts of Training on Willingness-to-Pay

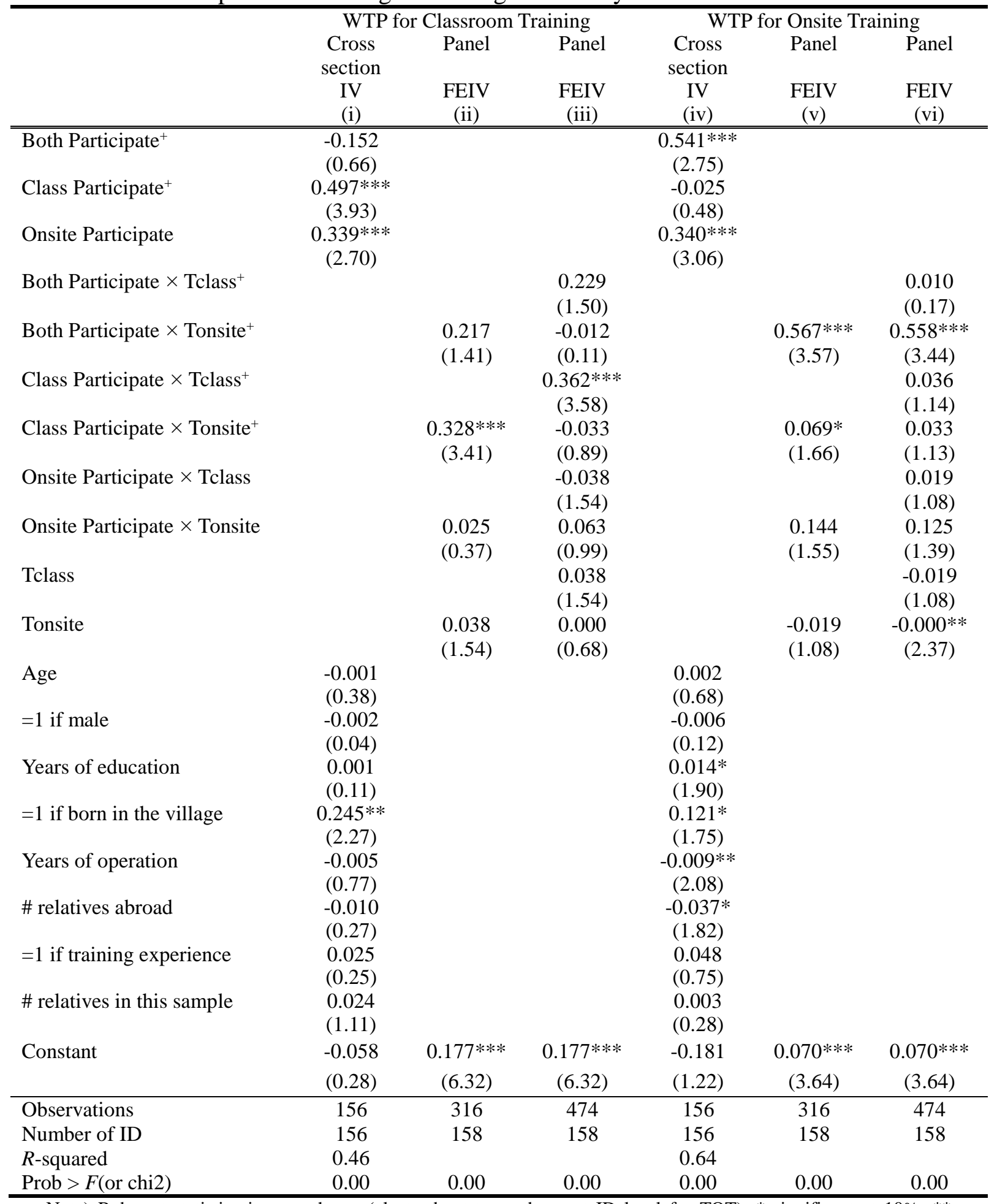

Note) Robust $t$ statistics in parentheses (cluster bootstrapped s.e. at ID level for TOT). ${ }^{*}$ significant at $10 \%$; ** significant at 5\%; *** significant at $1 \%$. Variables with + are instrumented with random invitation status. 
Table 6: Pre-Program Relation between the Total Scores and Performance

\begin{tabular}{|c|c|c|c|}
\hline & $\begin{array}{l}\ln \text { (Revenue) } \\
\text { (i) }\end{array}$ & $\begin{array}{l}\ln (\mathrm{VA}) \\
\text { (ii) }\end{array}$ & $\begin{array}{l}\ln \text { (Profit) } \\
\text { (iii) }\end{array}$ \\
\hline Total Score & $\begin{array}{c}0.186 * * * \\
(4.64)\end{array}$ & $\begin{array}{c}0.159 * * * \\
(3.18)\end{array}$ & $\begin{array}{c}0.160 * * * \\
(3.16)\end{array}$ \\
\hline Age & $\begin{array}{l}-0.019 \\
(1.56)\end{array}$ & $\begin{array}{l}-0.006 \\
(0.46)\end{array}$ & $\begin{array}{r}-0.007 \\
(0.51)\end{array}$ \\
\hline$=1$ if male & $\begin{array}{l}0.009 \\
(0.05)\end{array}$ & $\begin{array}{l}-0.143 \\
(0.57)\end{array}$ & $\begin{array}{l}-0.209 \\
(0.82)\end{array}$ \\
\hline Years of education & $\begin{array}{l}-0.008 \\
(0.22)\end{array}$ & $\begin{array}{l}-0.015 \\
(0.30)\end{array}$ & $\begin{array}{l}0.007 \\
(0.15)\end{array}$ \\
\hline$=1$ if born in the village & $\begin{array}{l}-0.093 \\
(0.15)\end{array}$ & $\begin{array}{l}1.326 \\
(1.51)\end{array}$ & $\begin{array}{l}1.007 \\
(1.13)\end{array}$ \\
\hline \# relatives abroad & $\begin{array}{c}0.444 * * * \\
(3.27)\end{array}$ & $\begin{array}{c}0.609 * * * \\
(4.14)\end{array}$ & $\begin{array}{c}0.491 * * * \\
(3.33)\end{array}$ \\
\hline$=1$ if have training experience & $\begin{array}{l}0.376 \\
(1.42)\end{array}$ & $\begin{array}{l}0.551 \\
(1.49)\end{array}$ & $\begin{array}{l}0.269 \\
(0.69)\end{array}$ \\
\hline Years of operation & $\begin{array}{c}0.048 * * \\
(2.26)\end{array}$ & $\begin{array}{l}0.027 \\
(0.95)\end{array}$ & $\begin{array}{l}0.044 \\
(1.60)\end{array}$ \\
\hline \# of relatives in this sample & $\begin{array}{c}0.124 * * * \\
(2.95)\end{array}$ & $\begin{array}{c}0.130 * * \\
(2.16)\end{array}$ & $\begin{array}{l}0.066 \\
(1.03)\end{array}$ \\
\hline Constant & $\begin{array}{c}9.779 * * * \\
(10.80)\end{array}$ & $\begin{array}{c}7.258 * * * \\
(5.59)\end{array}$ & $\begin{array}{c}7.386^{* * * *} \\
(5.52)\end{array}$ \\
\hline $\begin{array}{l}\text { Observations } \\
R \text {-squared }\end{array}$ & $\begin{array}{l}154 \\
0.30\end{array}$ & $\begin{array}{l}133 \\
0.22\end{array}$ & $\begin{array}{l}122 \\
0.21\end{array}$ \\
\hline
\end{tabular}

Note) Robust t statistics in parentheses. * significant at 10\%; ** significant at 5\%; *** significant at $1 \%$. 
Table 7: ITT Impacts of Training on Total Scores and Log of Material Costs

\begin{tabular}{|c|c|c|c|c|c|}
\hline & \multicolumn{3}{|c|}{ Total Scores } & \multicolumn{2}{|c|}{ Log of Material Costs } \\
\hline & $\begin{array}{l}\text { Cross } \\
\text { section } \\
\text { OLS } \\
\text { (i) }\end{array}$ & $\begin{array}{c}\text { Panel } \\
\text { FE } \\
\text { (ii) }\end{array}$ & $\begin{array}{l}\text { Panel } \\
\text { FE } \\
\text { (iii) }\end{array}$ & $\begin{array}{l}\text { Cross } \\
\text { section } \\
\text { OLS } \\
\text { (iv) }\end{array}$ & $\begin{array}{l}\text { Panel } \\
\text { FE } \\
\text { (v) }\end{array}$ \\
\hline Both Invite & $\begin{array}{l}0.429 \\
(0.46)\end{array}$ & & & $\begin{array}{l}0.056 \\
(0.12)\end{array}$ & \\
\hline Class Invite & $\begin{array}{c}0.996^{* *} \\
(2.35)\end{array}$ & & & $\begin{array}{l}0.205 \\
(0.95)\end{array}$ & \\
\hline Onsite Invite & $\begin{array}{c}5.024 * * * \\
(7.68)\end{array}$ & & & $\begin{array}{l}0.086 \\
(0.23)\end{array}$ & \\
\hline Both Invite $\times$ Tclass & & & $\begin{array}{c}1.137 * * \\
(2.50)\end{array}$ & & \\
\hline Both Invite $\times$ Tonsite $^{\ddagger}$ & & $\begin{array}{c}1.472 * * \\
(2.50)\end{array}$ & $\begin{array}{l}0.352 \\
(0.86)\end{array}$ & & $\begin{array}{l}0.271 \\
(1.14)\end{array}$ \\
\hline Class Invite $\times$ Tclass & & & $\begin{array}{c}1.287 * * * \\
(5.24)\end{array}$ & & \\
\hline Class Invite $\times$ Tonsite $^{\ddagger}$ & & $\begin{array}{c}1.309 * * * \\
(4.42)\end{array}$ & $\begin{array}{l}0.005 \\
(0.04)\end{array}$ & & $\begin{array}{l}-0.012 \\
(0.07)\end{array}$ \\
\hline Onsite Invite $\times$ Tclass & & & $\begin{array}{l}-0.144 \\
(1.32)\end{array}$ & & \\
\hline Onsite Invite $\times$ Tonsite $^{\ddagger}$ & & $\begin{array}{c}3.720 * * * \\
(17.55)\end{array}$ & $\begin{array}{c}3.847 * * * \\
(18.61)\end{array}$ & & $\begin{array}{c}-0.388 * * \\
(2.12)\end{array}$ \\
\hline Tclass & & & $\begin{array}{c}0.144 * * \\
(2.30)\end{array}$ & & \\
\hline Tonsite & & $\begin{array}{c}0.280 * * \\
(2.45)\end{array}$ & $\begin{array}{l}0.153 \\
(1.48)\end{array}$ & & \\
\hline Year2009 & & & & & $\begin{array}{l}0.017 \\
(0.28)\end{array}$ \\
\hline Year2010 & & & & & $\begin{array}{l}0.053 \\
(0.35)\end{array}$ \\
\hline Age & $\begin{array}{l}-0.004 \\
(0.16)\end{array}$ & & & $\begin{array}{l}-0.015 \\
(1.41)\end{array}$ & \\
\hline$=1$ if male & $\begin{array}{c}1.244 * * * \\
(3.01)\end{array}$ & & & $\begin{array}{l}0.264 \\
(1.48)\end{array}$ & \\
\hline Years of education & $\begin{array}{c}0.313 * * * \\
(3.96)\end{array}$ & & & $\begin{array}{c}0.083^{* * *} \\
(2.44)\end{array}$ & \\
\hline$=1$ if born in the village & $\begin{array}{c}1.526^{*} \\
(1.94)\end{array}$ & & & $\begin{array}{c}-0.405 \\
(1.49)\end{array}$ & \\
\hline Years of operation & $\begin{array}{l}0.025 \\
(0.65)\end{array}$ & & & $\begin{array}{c}0.039 * * \\
(2.04)\end{array}$ & \\
\hline \# relatives abroad & $\begin{array}{l}0.171 \\
(0.53)\end{array}$ & & & $\begin{array}{c}0.396^{* * *} \\
(3.83)\end{array}$ & \\
\hline$=1$ if training experience & $\begin{array}{c}1.902 * * * \\
(3.26)\end{array}$ & & & $\begin{array}{l}0.420 \\
(1.46)\end{array}$ & \\
\hline \# relatives in this sample & $\begin{array}{c}-0.008 \\
(0.08)\end{array}$ & & & $\begin{array}{c}0.140 * * * \\
(3.14)\end{array}$ & \\
\hline Constant & $\begin{array}{c}6.557 * * * \\
(4.21)\end{array}$ & $\begin{array}{c}11.186 * * * \\
(153.26)\end{array}$ & $\begin{array}{c}11.186 * * * \\
(134.89)\end{array}$ & $\begin{array}{c}10.636 * * * \\
(17.08)\end{array}$ & $\begin{array}{c}11.264^{* * * *} \\
(278.87)\end{array}$ \\
\hline Observations & 154 & 312 & 464 & 156 & 471 \\
\hline Number of ID & 154 & 158 & 158 & 156 & 158 \\
\hline$R$-squared & 0.62 & 0.79 & 0.76 & 0.24 & 0.01 \\
\hline Prob $>F($ or chi 2$)$ & 0.00 & 0.00 & 0.00 & 0.00 & 0.07 \\
\hline
\end{tabular}

Note) Robust t statistics in parentheses (clustered s.e. at ID level for ITT). * significant at $10 \%$; ** significant at 5\%; $* * *$ significant at $1 \%$. Variables with + are instrumented with random invitation status. ₹ The data used in this column are a panel of 2008, 2009, and 2010. Accordingly, Tonsite in these interaction terms in this column should read a dummy variable, Year2010, which indicates whether the year is 2010. 
Table 8: TOT Impacts of Training on Total Scores and Log of Material Costs

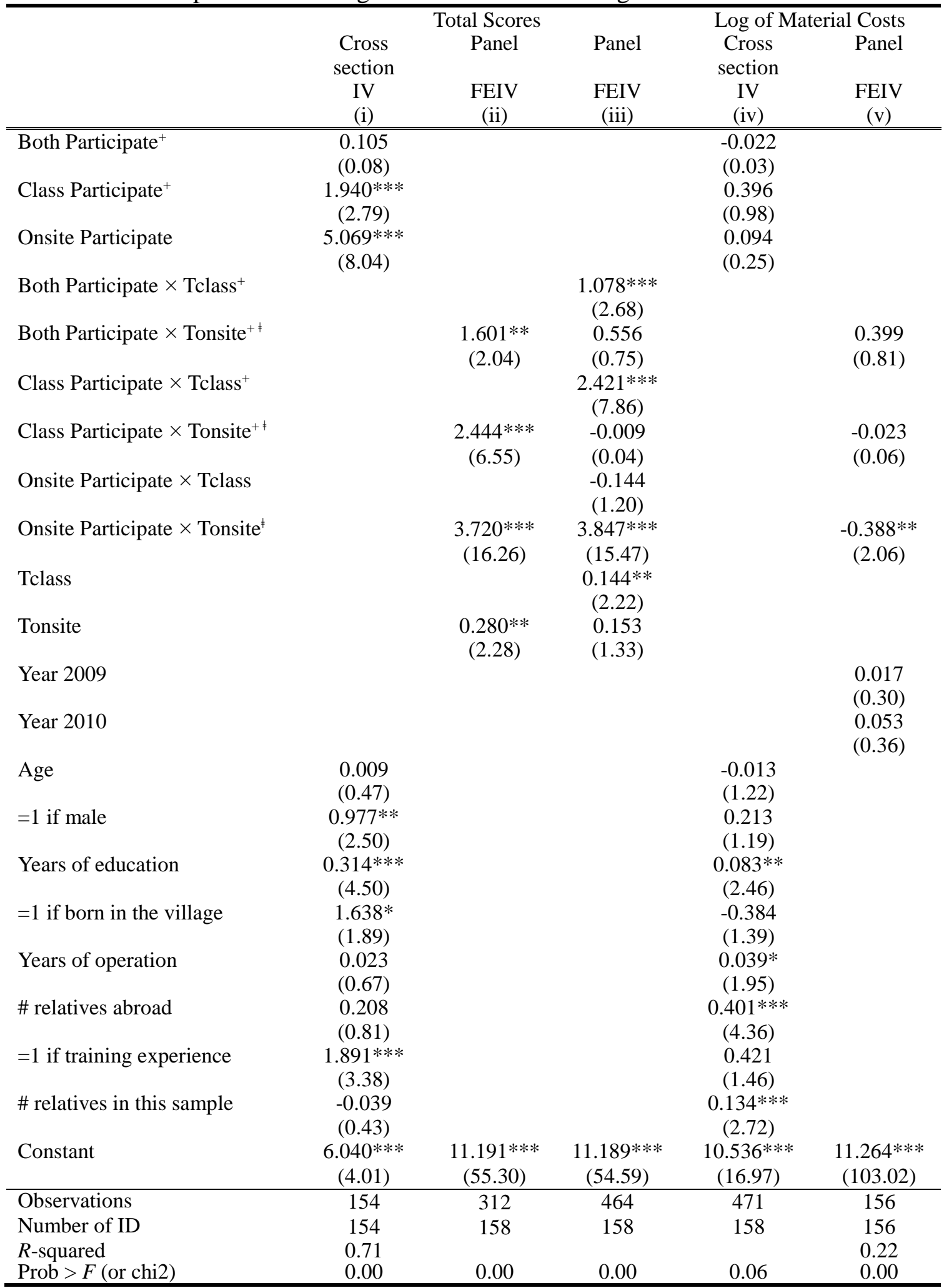

Note) Robust $t$ statistics in parentheses (clustered s.e. at ID level for ITT, cluster bootstrapped s.e. at ID level for TOT). * significant at 10\%; ** significant at 5\%; *** significant at $1 \%$. Variables with + are instrumented with random invitation status. $\neq$ The data used in column (v) are a panel of 2008, 2009, and 2010. Accordingly, Tonsite in these interaction terms in this column should read a dummy variable, Year2010, which indicates whether the year is 2010. 
Table 9: Estimated Linear Probability Model of Application of Learning after Training

\begin{tabular}{|c|c|c|c|c|}
\hline & \multicolumn{4}{|c|}{$\begin{array}{c}=1 \text { if implemented something learnt after } \\
\text { participating in: }\end{array}$} \\
\hline & \multicolumn{2}{|c|}{ Classroom Training } & \multicolumn{2}{|c|}{ Onsite Training } \\
\hline & (i) & (ii) & (iii) & (iv) \\
\hline \multirow[t]{2}{*}{ Age } & -0.004 & -0.003 & -0.013 & -0.013 \\
\hline & $(1.07)$ & $(1.03)$ & $(1.41)$ & $(1.37)$ \\
\hline \multirow[t]{2}{*}{$=1$ if male } & 0.054 & 0.057 & -0.056 & -0.065 \\
\hline & $(0.80)$ & $(0.85)$ & $(0.32)$ & $(0.38)$ \\
\hline \multirow[t]{2}{*}{ Education } & -0.029 & -0.030 & $-0.067 * *$ & $-0.065 *$ \\
\hline & $(1.56)$ & $(1.58)$ & $(2.05)$ & $(1.87)$ \\
\hline \multirow[t]{2}{*}{ Years of operation } & -0.005 & -0.004 & -0.016 & -0.019 \\
\hline & $(0.35)$ & $(0.34)$ & $(0.96)$ & $(1.10)$ \\
\hline \multirow[t]{2}{*}{$=1$ if have training experience } & -0.052 & -0.051 & 0.089 & 0.059 \\
\hline & $(0.32)$ & $(0.32)$ & $(0.35)$ & $(0.23)$ \\
\hline \multirow[t]{2}{*}{ \# relatives abroad } & -0.033 & -0.043 & 0.075 & 0.068 \\
\hline & (1.09) & $(1.29)$ & $(1.65)$ & $(1.54)$ \\
\hline \multirow[t]{2}{*}{ Total score before classroom training } & 0.020 & 0.024 & & \\
\hline & $(1.36)$ & $(1.57)$ & & \\
\hline \multirow{2}{*}{$\begin{array}{l}\text { Willingness-to-pay for classroom training before } \\
\text { classroom training }\end{array}$} & 0.061 & & & \\
\hline & $(1.24)$ & & & \\
\hline \multirow{2}{*}{ Total score before onsite training } & & & 0.024 & $0.033 *$ \\
\hline & & & $(1.30)$ & $(1.78)$ \\
\hline \multirow{2}{*}{$\begin{array}{l}\text { Willingness-to-pay for onsite training before onsite } \\
\text { training }\end{array}$} & & & $0.194 * *$ & \\
\hline & & & $(2.14)$ & \\
\hline \multirow[t]{2}{*}{ Constant } & $1.124 * * *$ & $1.087 * * *$ & $1.743 * *$ & $1.698 * *$ \\
\hline & $(3.93)$ & $(4.09)$ & $(2.28)$ & $(2.12)$ \\
\hline Observations & 52 & 52 & 46 & 46 \\
\hline$R$-squared & 0.12 & 0.11 & 0.20 & 0.16 \\
\hline Dependent variable mean & \multicolumn{2}{|c|}{$94.2 \%$} & \multicolumn{2}{|c|}{$85.4 \%$} \\
\hline standard deviation & \multicolumn{2}{|c|}{0.24} & \multicolumn{2}{|c|}{0.36} \\
\hline
\end{tabular}

